ではあるまいか，気管支狭窄症ならば当然無気 肺像を呈乙, 又赤沈值の克進も必要であろう。 但し炎症は岕つたのであるから，パラキシンに 上り反応乙て, 漸次炎症々状は消退し, 分泌物 の減少と共に喘息症状孔減退して行つたと考光 て良いのではあるまいか。

気管支喘息の治癒と云う事は, 短期間で断定 すべきるのでない事は, 既に先人の警める処で ある。本年発症を見ね事を即ち治癔と即断すべ きものでも女るまい。间後佮経過を観察する積 りである。

\section{結論}

難治の気管支喘息に於て，気管支鏡検査によ
り, 右 B6 支口の強度の炎症性狭第を発見し, 抗生剤の局所注入により速に喘息発作の消退を 得さ吇る事の出来た，興味むる一例を報告し た。

\section{主要交献}

1）水野：気食会誌， 7 巻 4 号

2) 水野：気食会誌， 8 巻 3 号

3）水野：気食会誌， 6 巻 4 号

4) 組織療法 (青木書店) 1954

5) Unger : Bronchial Asthma (Thomas) 1950

6) Wyss : Asthma bronchiale (Thieme) 1955

\title{
肺結核及気管・気管支結核における 気管支分泌物の細胞学的研究
}

（第 1 報）

気管支分泌物の細胞学的研究は, 肺癌の診断 法として近年注目され諸学者により研究されて 居る。併し肺結核患者に於祆る肺内病変がどの 程度迄気管支分泌物の細胞成分に変化を与光る かに関しては，比較的研究も少ない。私共は， 気管・気管支結核患者に於て局所にストマイを 注入し，その気管支分泌物の変化を比較的長期 間にわたり観察したので茲に少数例ではあるが 報告する。

1）被検材料は，日大板橋病院耳鼻咽喉科外 来を訪れた気管支結核患者の局部分泌物を使用 した。

2）検查方法 同一患者に就いて毎週又は隔 週経気管支鏡的に採取せる分泌物の塗抹標本を

* 日本大学医学部耳鼻咽喉科教窒 (主任 中村匹郎教授)

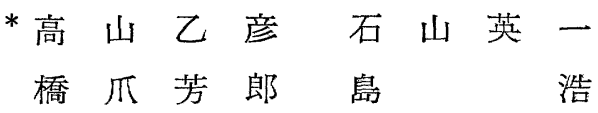

作製した。即や分泌物を病変部附近より取り， オベクトグラスに塗抹し乾燥させる事なく值ち に95\%アルコール・エーテル等量液に固定しパ パニコラー染色を行つた。又気管支病変は小野 氏分類法に従つた。検查した症例は次の 5 例で 有るが臨床症状のうちX線所見と気管支鏡所見 以外少略する。又各例共検査の都度病変部に ストマイ $0.5 \mathrm{~g}$, 三蒸溜水 $2.5 \mathrm{cc}$ に溶解して注 入した。

第1例 25 才男子。発病は昭和29年 7 月で左 肺結核の診断をうけ S.M 及び PAS 加療をし 昭和 31 年 10 月 29 日当科初診の患者で有る。初診 時の気管支鏡所見は，気管分岐部より左主気管 支にわたり $5 \mathrm{~cm}$ 程著明な発赤有り, 特に分岐 部より 2〜 3cm の右側壁に針尖大の潰厦 2 ケを 認めその他の部には異常所見を認めなかつた所 謂気管支結核 3 型の症例で有る。結核菌は, 塗 
表



但し（卅)極めて多数，(サ)は多数，(十)は少数、(一)は殆んど認められないもの，

抹, 培養共に陰性。この患者に頻回反覆し分泌 物を検査して得た所見は第 1 表の如くで有る。 現在同患者の気管支鏡所見は初診時より非常に 改善され，潰瘍は殆んど認められず瘕痕様とな り発赤も軽度となつた。

第 2 例 44 才女子。昭和 30 年春発病し，左上 葉の肺結核症で S.M 及び PAS の加療中で有 る。31年12月19日に当科初診でその時の所見 は，気管分岐部に異常所見を認めず左主気管支 は分岐部より数 $\mathrm{cm}$ にわたり潅漫性の発赤を示 乙第 1 例同様針尖大の潰愓を有し，更に左上某 支分岐部孔著明な発赤を認め，その他の部位に は異常所見を認めなかつたのである。この症例 も所謂気管支結核 3 型で所見は第 2 表の如くで 有る。倚喀痰の叙抹培養検查はすべて陰性でめ つた。同患者の最近の所見は次第に改善され左
主気管支の発赤は減少し潰愒は見られない様に なつて来た。

第 3 例 41 才女子。昭和 30 年 4 月発病, 右上 葉肺結核として S.M 交び PAS の治療をうけ 昭和 32 年 1 月 24 日当科浣した。初馀時所見 は気管分岐部は肥厚し右主気管支は濔漫性にや や浮腫性, 増殖肥厚を示し, 他の部位には異常 所見を劲めない所謂 1 ～型の病変であつた。 結核菌は塗抹，培養共に陰性で所見は第 3 表の 如くである。最近の気管支鏡所見は初診時と大 差なく改善の徵候は見られない。

第 4 例 28 才女子。昭和17年秋発病し喀血が あつたがそのまま放置, 27 年夏より $\mathrm{SM}$ 及び PAS の加療をうけ，31年10月 8 日当科を訪れ た。喀痰中結核菌は陰性。初診時所見は気管は 軽度の発赤を示し分岐部は旅漫性に 発 赤 腫 脹 


\section{2 表}

\begin{tabular}{|c|c|c|c|c|c|c|c|c|c|c|c|c|c|}
\hline 2例 & \multicolumn{4}{|c|}{ 44저우 } & \multicolumn{9}{|c|}{ 気管支結核 3 度 } \\
\hline 細 胞 & 1 & 2 & 3 & 4 & 5 & 6 & 7 & 8 & 9 & 10 & 11 & 12 & 13 \\
\hline 円柱上皮 & 册 & 世 & 曲 & 世 & 册 & 册 & 世 & $\mathrm{m}$ & 世 & - II & 世 & 世 & 世 \\
\hline 聏平上皮 & - & + & - & - & - & - & + & - & - & - & - & + & 一 \\
\hline 多形核白血球 & 世 & 世 & 世 & m & 世 & m & 世 & 曲 & 曲 & \# & m & Ht & 曲 \\
\hline 1ンハ球 & + & + & + & + & + & + & + & + & + & + & + & + & + \\
\hline 單 球 & + & + & + & + & + & + & + & + & + & + & + & + & + \\
\hline 好 酸 球 & - & - & 一 & - & - & - & - & - & 一 & 一 & - & - & 一 \\
\hline 赤血球 & + & + & \# & $H$ & + & H & + & H & + & H & + & + & + \\
\hline 組 織 球 & H & H & $H$ & H & + & H & H & H & H & + & H & $H$ & + \\
\hline 巨細，胞 & - & - & - & - & - & - & - & - & 一 & - & 一 & - & - \\
\hline 分泌物培養 & - & & - & & & & & & & - & & & \\
\hline 気 & & & &  & & & & & & & & & \\
\hline
\end{tabular}

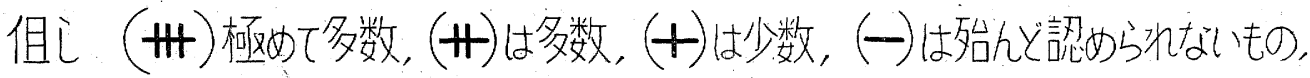

乙, 左主気管支は著明の発赤を示す外は異常所 見を認めない所謂 1 型のbので，この患者の所 見は第 4 表の如くで有る。最近の所見では，発 赤腫脹は著明に減退し左主気管支に僅かの発赤 を残す程度に俥快した。

第 5 例 39 才男子。昭和 25 年 4 月発病し S.M 及び PAS 加療を行つたが悪化し, 両側肺結核 症の診断にて昭和 32 年 4 月 17 日当科を訪孔引続 き入院加療中の患者である。喀痰検査は培養で も結核菌を認めない。初診時所見は気管及び気 管分岐部には著変なく，左主気管支は強度に発
赤腫脹し, 又右主気管支と, 上某支分岐部及中 葉支分岐部には軽度の発赤を認めた所謂 1 度気 管支結核である。その所見は第 5 表の如くで， 最近の所見は初診時同様で末だ改善されていな い。

成績 気管支分泌物の検查で叙抹標本中に出 現する細胞成分は上皮性細胞及び非上皮性細胞 の二群に大別される。

（I）上皮性細胞群

(a) 円柱上皮 毎回無数に認められるが量的 な変化は見られず初診時より病変軽減せる症例 
3 表



4 表

4例 28才우 気管支結核 1 度

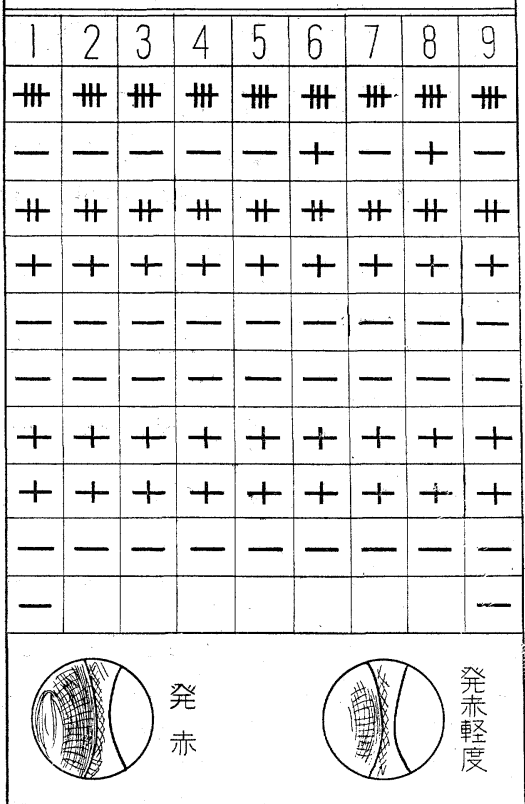

但し（卅）は極めて多数、(サ)は多数、(十)は少数、(一)は殆んど認めら扎ないもの、

(1:2:4) に於いても変動は見られなかつた。 全体の特徵として円柱上皮はその正常型を認め るものがなく線毛欠如し核は偏在して見られ， 又円柱上皮より剝脱せる細胞が重積を示す場合 も見られた。

(b) 扁平上皮 扁平上皮は分泌物中に非常に 少なく全例に於いて殆んど認められなかつた。 これは気管支構造上よりも当然と思われる。

\section{（II） 非上皮細胞群}

(a) 多形核白血球 全症例汇於いて毎回多数 諗められた。併し第 $1 \cdot 3$ 例に於いては次第に減 少を示し，第 2 例は日を経ても変化は殆んど䞏 められなかつた。又気管支結核第 $1 \cdot 2$ 度の病変 に於いては第 3 度のものに比して少ない様に思 われるが例数が少ないので判然とした事は言え ない。

(b) リンパ球 全例に於いて少数出現を見て いるが各例に於いても毎回認められ増減を見な かつた。併し 3 例目の浮腫性肥厚性粘膜に於い
ては他の例よりも比較的多数諗められた。

(c) 単球 第 $2 \cdot 3$ 例に於いては毎回少数認め られたがその他の症例に於いては諗められず又 認められた症例に於いて子数の変動はないよう であつた。

(d) 好酸球 全例に於いて認められなかつ た。

（e）組織球（所謂剝離肺胞上皮様細胞）第 $1 \cdot 2 \cdot 3$ 例に於いては各々初診時よりその数を減 じて来ている。第 4.5 例に於いては変化は認め られない。これは症例少なく判然とした事は云 い難いのであるが前記白血球と共に気管・気管 支結核患者に於いてその分泌物中に重要な位置 を示すものの様で有る。

（f） 赤血球 全例に於いて赤血球を認めたが 特に第 $1 \cdot 2 \cdot 5$ 例に於いては比較的多数を認め た。

(g) 巨細胞 全例に於いて毎回の検查時にも ラングハンス細胞を認め得なかつた。 


\section{5 表}

\begin{tabular}{|c|c|c|c|c|}
\hline \multicolumn{5}{|c|}{ 5例 39才令気管支結核|度 } \\
\hline 細 胞検查回数 & 1 & 2 & 3 & 4 \\
\hline 円柱上皮 & 世 & 世 & 世 & 世 \\
\hline 侖平上皮 & - & - & - & - \\
\hline 多形核白血球 & H & H & \# & H \\
\hline リソパ球 & + & + & + & + \\
\hline 單 & + & 一 & + & - \\
\hline 好 酸 球 & - & 一 & - & - \\
\hline 赤血 球 & \# & + & H & + \\
\hline 組 織 球 & + & H & \# & + \\
\hline 巨細，胞 & - & 一 & - & - \\
\hline 分泌物培養 & & - & & \\
\hline & & & & \\
\hline
\end{tabular}

考察：先に比企・鈴木氏等は最近の化学療法 に伴なう肺結核患者喀痰の細胞变化を追求し又 結核性気管支分泌物については Clerf, Herbert, Emil Steen, 室津, 井上氏等によつて種々研究 がなされて居る。私等は肺結核患者の気管支分 泌物を局所的治療経過と共に追求し, 前記の如 き所見を得たのでいささか考察して見たいと思 弓。そもそも気管支分泌物の検查方法としては (A)塗抹標本による方法と (B)パラフィン包埋切片 による方法とに大別されるが，私共は便宜上(A) の方法に依つた。又分泌物の採取は直達用挾綿 子を使用した。気管分泌物採取器を使用試みた が，手技の不手際と分泌物少量の場合は思 ら様
な所見が得られなかつたので挾綿子に替えたの である。挾綿子では何うしても粘膜を損傷する ので細胞観察には不便を来たした。気管支分泌 物は，刎論肺胞及気管支よりの細胞成分の混合 物であつて，塗抹標本中の細胞成分がすべてそ の局所よりのものとは考兄られない。又塗抹 標本中に出現する細胞は組織表層の剝落細胞で 有り深部の細胞は塗抹標本には現われない。そ の為に全例に於て毎回多数に認められた円柱上 皮が正常型を示するの少なく，線毛久如乙核も 扁在し剥落細胞が重積を示し，ラングハンズ細 胞子誌め得なかつたと考えられる。次に気管支 結核の種類による細胞成分の特徵を検したが， 第 6 表の如き成績を得た。即ち気管支結核は I 型より II 型III型に組織球と多形核白.血球が多量

\section{表 6}

\begin{tabular}{|c|c|c|}
\hline \multicolumn{3}{|c|}{ 治療による細胞数変化 } \\
\hline 病型 & 組 織 球 & 多形核白血球 \\
\hline 型 & $+\rightarrow+$ & $H \rightarrow H$ \\
\hline 型 & $H \rightarrow+H$ & $H \rightarrow H$ \\
\hline 型 & $H H \rightarrow H+$ & $H \rightarrow H$ \\
\hline
\end{tabular}

に出現し，局所治療をすすめると，日を追つて 組織球も多形核白血球も減少し，I型に近づい て来る様な結果を得た。之は肉眼的所見に於て も軽状を認めた様に思われた。即ち病巣の治癒 機転と細胞変化に多少相関が有る様に思われた のである。乙か乙症例が少数なので明確に断言 は出来ない。又この事は非結核性気管支分泌物 と比較検討する事が重要と考光られる。他の細 胞群では赤血球が全例に於て認められ又淋巴球 は一例だけに比較的多数認められたものもある が何九とも云立ないと思う。其他に於ては今迄 のところ見るべき変化は認好られなかつた。併 し気管支分泌物では結核の治癒機転は論じ難 くめくまでも分泌物の細胞検査とレ線並びに臨 床所見とを綜合して判断する事は勿論である。 今回は全例に於いて結核菌は塗抹でも培養でも 陰性であつたが勿論ストマイ耐性検査も必要と 考光られる。文治療は局所にストマイを注入し 
たに過ざないので，病巣にストマイを注射した ら分泌物上飞異つた変化が現われるのではない かと考它此等の点を将来追求して見たいと思 弓。更に症例を追加し, 非結核性気管支分泌物 とも此較検討したいと考える。

\section{結論}

1）気管支分泌物の塗抹標本中に現われる上 皮性細胞と気管支病変との間には判然とした関 係は見られない様に思う。

2）非上皮性細胞群中では多形核白血球と組 織球が細胞成分に変化を来たす関連性の大なる ものである椂に思われる。又同細胞は局所治潦 を続けた結果では次第に減少する傾向が有り， 局所所見は肉眼的にも俥快に向弓様に思う。

3）リンパ球, 単球, 好酸球に於いては著明 な変動を認める事は出来なかつた。

4）ラングハンス巨細胞は認められなかつ た。

5）分泌物の頻回検查のみにて病変の増減を 論じる事はむづかしいものと思われる。

稿を終るに当り, 中村四郎教授の御校閲を感謝致 します。尚本稿は昭和32年10月19日神戸医大に於け る第 9 回日本気管食㨁科学会総会に执いて発表した。

\section{交献}

1）石川七郎・竹内慶治：結核研究の 進 歩 8,97 , 1954

2）小野譲・石川七郎：胸部外科 6, 384, 1953

3）小野譲：気食会報, 3 巻 1 号

4) Herbert, P. A. and Clerf, L.H.T.A.M.A. 130, 1006, 1946

5) Woolner, L,B, and McDonald, T,R ; Am Int, Med, 53, , 1164 1174, 1950

6) Clerf, L, H and Herbert, P,A ; Am Rev, Tbc, Vol 54, No. 6 Dec 1946

7) 室津健司：医療， 6 巻 3 号, p. 5

8）比企能達：結核，27巻 9 号，p. 4

9) Papanicolaou, G. N and Gramvell ; H. Dis, Chest, 15, 412, 1949

10）日本医事新報, No. 1696 , p. 105

11）井上雅夫：気食会報， 4 巻, p. 13

12) Watson, W,L etal ; J. thor. Surg, 18, 113 122. 1949

13) Richardson, H.L. and Hunter, W.C.; Am J Clin Path, 19, 323, 1946

14）牧野，神津：肺結核の気管支鏡検査法, (1950)

15）小河, 長沢々の他：気食会, 報 4 巻, p. 56

\section{結核性気管支狹窄症に対するブジ一療法の検討}

\section{緒言}

近年，気管気管支結核症注対して，気管支鏡 飞依る検查並び治療が施行されて以来, 気管 支結核に対する治療效果の著しい進歩が認めら れつつ岕る。最近私共は長期任亘る虚脱療法 (人工気胸), 及び PAS を使用した肺結核患 者で左主気管支に狭窄を認め, 左側不透明肺を 呈した一症例飞遭遇し,この治療法として気管

* 日本大学医学部 耳鼻咽唉科学教室 (主任 中村四郎教授)

$$
\begin{array}{cccccc}
* \text { 高山乙彦山出 } & \text { 勝彦 } \\
\text { 小 } & \text { 直之 } \text { 堀 } \text { 川基 治 }
\end{array}
$$

支鏡的に，ブジ一拡張を長期間に亘り施行して その経過を観察する機会を得たので茲涬友告す る。

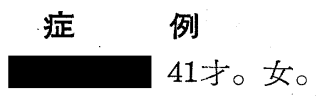

昭和 25 年 5 月末, 感冒に罹患後, 嗄声を生 じ， 6 月某病院を訪れた処，喉頭結核と診断さ れ更に内科飞受診, 左肺結核と診断され化学療 法 (PAS) を開始し，装年 2 月より気胸を 1 週 1 回の割で約 2 年間続けた。29年 5 月X線写真 にて無気肺の状態であるから肺切除の必要あり 